\title{
Klimat Zagłady (w perspektywie powieści Pawła Huellego, Tadeusza Konwickiego, Andrzeja Kuśniewicza i Piotra Szewca)
}

Marta Tomczok

TEKSTY DRUGIE 2017, NR 2, S. 147-165

DOI: $10.18318 /$ td.2017.2.8

\section{Wprowadzenie: klimat zmian}

Opowiadając o losach powojennej literatury polskiej o Zagładzie, Bartłomiej Krupa sięgnął po metaforę zaskakująco bliską środowiskowej historii Holokaustu. Określając lata 8o. „trzecią odsłoną tematyki żydowskiej w Polsce" i „jej ponownym dyskursywnym wyłonieniem"1, Krupa, podobnie jak inni badacze ${ }^{2}$, za najważniejsze i inicjalne wydarzenia tamtych czasów uznał wyemitowanie w październiku 1985 roku przez Telewizję Polską filmu Shoah Claude'a Lanzmanna oraz późniejszy o dwa lata esej Biedni Polacy patrza na getto Jana Błońskiego opublikowany w „Tygodniku

1 B. Krupa Opowiedzieć Zagładę. Polska proza i historiografia wobec Holocaustu (1987-2003), Universitas, Kraków 2013, s. 57.

Por. M. Steinlauf Pamięć nieprzyswojona: polska pamięć Zagłady, przeł. A. Tomaszewska, Cyklady, Warszawa 2001, s. 108-142; P. Czapliński Zagłada - niedokończona narracja polskiej nowoczesności, w: Ślady obecności, red. S. Buryła, A. Molisak, Universitas, Kraków 2010, s. 341-345. P. Forecki Od "Shoah" do "Strachu". Spory o polsko-żydowskq przeszłość i pamięć w debatach publicznych, Wydawnictwo Poznańskie, Poznań 2010, s. 115-165.

\section{Marta Tomczok -}

doktor habilitowana, adiunkt w Instytucie Nauk o Literaturze Polskiej Uniwersytetu Śląskiego w Katowicach, autorka książek Trofea wyobraźni. O prozie Leo Lipskiego (2011) i Metonimie Zagłady. O polskiej prozie lat 1987-2012 (2013). Wspólnie z Przemysławem Czaplińskim i Renatą Makarską redagowała Poetykę migracji. Doświadczenie granic w literaturze polskiej przełomu XX i XXI wieku (Katowice 2013). Redaktor naczelna rocznika "Narracje o Zagładzie". Kontakt: martacuber@interia. pl 
Powszechnym”3. Rok 1987 przyniósł „prawdziwą lawinę publikacji”4 i, jak napisał Krupa, okazał się czasem pełnym nie tylko ważnych i do dzisiaj dyskutowanych książek; okazał się czasem lawiny wypowiedzi o Zagładzie, w którym badacz intuicyjnie zobaczył historię i geologię jako całość, co w świetle moich rozważań - ukierunkowanych na związek Zagłady ze środowiskiem naturalnym - wydaje się spotkaniem o ważnych konsekwencjach społecznych i intelektualnych ${ }^{5}$.

Metafora geologiczna Krupy, w której chciałabym widzieć więcej niż frazeologizm, wchłonęła wiele publikacji z 1987 roku, w tym m.in. Kadisz Henryka Grynberga, Nawrócenie Andrzeja Kuśniewicza, Zagładę Piotra Szewca, Piołun i popiót Romana Zimanda czy Skrawek czasu Idy Fink ${ }^{\mathbf{6}}$, czyli książki, które w jednym tylko roku znacząco wzbogaciły piśmiennictwo pozagładowe. Pozbawiła je jednak głębszych związków i relacji. Jednemu z takich związków, związkowi czterech powieści z lat 1986-1987 z historią środowiskową Holokaustu, chciałabym przyjrzeć się uważniej. Zmiana klimatu intelektualnego, jaka nastąpiła w ósmej dekadzie ubiegłego wieku w wyniku „odmrożenia”, a później „ocieplenia” tematyki żydowskiej w polskim dyskursie filmowym, literackim, politycznym i publicystycznym, została - w ściśle metaforycznym sensie - zapisana w czterech różnych wariantach

3 J. Błoński Biedni Polacy patrzą na getto, Tygodnik Powszechny" 1987 nr 2, s. 1, 4.

4 B. Krupa Opowiedzieć Zagładę..., s. 6o. Zwrotu „rusza lawina” w związku z powrotem tematyki żydowskiej w połowie lat 80. pierwszy użył Przemysław Czapliński. Por. P. Czapliński Prześladowcy, pomocnicy, świadkowie. Zagłada i polska literatura późnej nowoczesności, w: Zagłada. Współczesne problemy rozumienia i przedstawiania, red. P. Czapliński, E. Domańska, Wydawnictwo „Poznańskie Studia Polonistyczne”, Poznań 2009, s. 155. Z kolei określeniami „burza”, "eksplozja" i „wiosna" w stosunku do tej samej problematyki posłużyła się Anna Mach w monografii Świadkowie świadectw. Postpamięć Zagłady w polskiej literaturze najnowszej, Fundacja na Rzecz Nauki Polskiej, Warszawa-Toruń 2016, s. 115. Niestety późniejsze konstatacje autorki, oparte na ograniczonym materiale, przeczą znaczeniu użytych przez nią metafor, głównie dlatego, że Mach przedstawia ósmą dekadę XX wieku jako czas pozbawiony nowej narracji i czerpiący "z wizerunków stereotypowych i literackich utrwaleń, także tych antysemickich", tamże, s. 225.

5 Metaforyką geologiczną w odniesieniu do rozważań na temat Zagłady posłużyła się przede wwszystkim kanadyjska pisarka Anne Michaels w powieści Fugitive Pieces z 1996 roku. Por. F. Quenette Between Earth Science and Language/Writing Imagery: How to Render the Workings of Memory in Anne Michaels' Fugitive Pieces, w: http://www.oalib.com/paper/2936515\#. V4eoOfmLRhE (14.07.2016). A także: C. Coussens "Secrets of the Earth": Geology and Memory in Anne Michaels's Fugitive Pieces, w: Annals of the University of Craiova, Series: Philology, English, year XI, No. 2, 2010, s. 73-88.

6 Tamże, s. 61. 
w Bohini Tadeusza Konwickiego, Nawróceniu Andrzeja Kuśniewicza, Zagładzie Piotra Szewca i Weiserze Dawidku Pawła Huellego. Jest to zapis odpowiadający, przynajmniej częściowo, losom tematów żydowskich w Polsce po 1985 roku, który zwraca uwagę czytelnika na ich gwałtowny powrót, pozbawiony jeszcze wówczas wyraźnych rysów zjawiska. Refleksja klimatyczna tworzy we wspomnianych powieściach warstwę metaliteracką w najbardziej umownym znaczeniu. $\mathrm{O}$ wiele ważniejsze wydają się dwa inne jej aspekty. Pierwszy dotyczy Zagłady i opowiadania o niej za pomocą metonimii, składających się z odniesień zarówno do historii, jak i do gwałtownych zjawisk pogodowych. Drugi odnosi się do zmian klimatu, nie tylko w Polsce, które od początku lat 8o. postrzega się jako sumę działań człowieka i czynników naturalnych ${ }^{7}$, a od przełomu lat 8o. i 9o. czyni częścią debaty publicznej na temat globalnego ocieplenia, powiązanej z rozpoznaniem skutków globalizacji ${ }^{8}$.

\section{Założenia i zastrzeżenia}

Przyjrzyjmy się rozgrywającej się w czasie wojny scenie wyprowadzania Żydów z kresowego miasteczka, opisanej przez Andrzeja Kuśniewicza w Nawróceniu:

Potem - pamiętam doskonale - cień wielkiej chmury pokrył słoneczne łąki, białe sierpnie i złote wrześnie ciężką powłoką dyszącej mgły i smugą gryzącego dymu. $Z$ uniesionymi nad głową rękami, założonymi na karki, wyszli z domostw, z naszej karczmy, z dwu sąsiednich bielonych zabudowań. Pobożni ludzie wzdrygający się golić zarost twarzy oraz odsłaniać głowy przed ludźmi. Ktoś powiedział głośno obok mnie, wyzierając przez okno od różowego salonu: - O, Berek też... I Mojsze... [...]. Odnotowano tego dnia w kieszonkowym kalendarzyku: „Od świtu mglisto. Zagarnięto dzisiejszego ranka co do jednego od nas oraz z dwu sąsiednich wsi [...]. Wdziałem dziś, bo pochłodniało, zamiast spodni

7 Warunki klimatyczne i oceanograficzne w Polsce i na Bałtyku Południowym. Spodziewane zmiany i wytyczne do opracowania strategii adaptacyjnych w gospodarce krajowej, red. J. Wibig, E. Jakusik, Instytut Meteorologii i Gospodarki Wodnej -Państwowy Instytut Badawczy, Warszawa 2012 , s. 5 .

8 D. Chakrabarty Klimat historii. Cztery tezy, przeł. M. Szcześniak, „Teksty Drugie” 2014 nr 5 , S. 170. 
beżowych te brunatne $\mathrm{z}$ tweedu i do nich zamszową kurtkę nabytą rok przed wojną na Koertnerstrasse we Wiedniu". (N, 59) ${ }^{9}$

Narracja, choć przypomina wspomnienie, jest mistyfikacją. Urodzony w 1904 roku Kuśniewicz wojnę spędził z dala od rodzinnych, położonych nieopodal Sambora, Kowenic. Najpierw przebywał we Francji, później został więźniem karnego obozu w Neue Bremm i obozu koncentracyjnego w Mauthausen ${ }^{\mathbf{1 0}}$. Nawrócenie nazwał spłaceniem „długu tym ludziom, o których losie dowiedziałem się dopiero pod koniec wojny, w obozie koncentracyjnym, od osób świeżo przybyłych. Były to wtedy strzępki wiadomości. Jak było na terenach polskich, dowiedziałem się jeszcze później"11. W odtworzonej ze „strzępków” historii, oprócz prawdopodobnej narracji świadka, ważną rolę powierzył pisarz klimatowi. Żydzi opuszczają miasteczko w dymie i mgle, a nad ich głowami wisi „cień wielkiej chmury”. Chmura występuje tu jako świadek Zagłady, nadaje wydarzeniu wzniosły charakter i podkreśla jego tragizm. Jednocześnie jednak usuwa je w cień, osłania i zakrywa. Dlaczego tak się dzieje i czy obecność mgły oraz dymu można wytłumaczyć nagłą, towarzyszącą eksterminacji zmianą klimatu, tego nie wiemy. Wiadomo natomiast, że dla narratora wspomniana zmiana ma zupełnie inny wymiar. Zachęca go przede wszystkim do włożenia cieplejszego stroju. Ostatnie zdanie sceny to prowokacja pisarza i podkreślenie rozziewu między historyczną niewiedzą bohatera a jego rozumieniem teraźniejszości. To także, wedle określenia Haralda Welzera, przykład shifting baselines, czyli „zmieniających się punktów odniesienia", zjawiska istotnego zarówno dla psychologów środowiskowych, jak i dla historyków ${ }^{12}$.W Wojnach klimatycznych Welzera shifting baselines oznaczają zarówno dezorientację ludzi w odniesieniu do środowiska fizycznego (Welzer sięga po obraz łąk i wrzosowisk, który dla współczesnych

9 W dalszej części tekstu przyjmuję oznaczenia: N - Nawrócenie Andrzeja Kuśniewicza (A. Kuśniewicz Nawrócenie, Wydawnictwo Literackie, Kraków 1997); B -Bohiń Tadeusza Konwickiego (T. Konwicki Bohiń, Czytelnik, Warszawa 1988); Z - Zagłada Piotra Szewca (P. Szewc Zagłada, Wydawnictwo Literackie, Kraków 2003); WD - Weiser Dawidek Pawła Huellego (P. Huelle Weiser Dawidek, słowo/obraz terytoria, Gdańsk 2000).

A. Kuśniewicz Puzzle pamięci. Z Andrzejem Kuśniewiczem rozmawia Grażyna Szcześniak, Wydawnictwo Eureka, Kraków 1992, s. 21-25.

Tamże, s. 67.

12 H. Welzer Wojna klimatyczna. Za co będziemy zabijać wXXI wieku, przeł. M. Sutkowski, Wydawnictwo Krytyki Politycznej, Warszawa 2010, s. 176. 
jest obiektem podziwu, a nie historycznej obserwacji związanej z wycinką drzew), jak i natury historii (zwykle nie do uchwycenia w realnym czasie, jak w przytoczonym przez Welzera fragmencie Dzienników Franza Kafki z 2 sierpnia 1914 roku: „Niemcy wypowiedziały Rosji wojnę. Po południu kurs pływania"13). Przykładem bardzo szczególnych shifting baselines, łączącym spojrzenie Kuśniewicza z wywodem Welzera, wydaje się Holokaust. Na zrozumienie tego połączenia pozwala środowiskowa historia Zagłady. W ujęciu Jacka Małczyńskiego badania prowadzone w jej obrębie stwarzają szansę na uzupełnienie „brakujących opracowań poświęconych sposobom reprezentacji przyrody w przedstawieniach Zagłady czy praktykom obchodzenia się z naturą w muzeach-miejscach pamięci powstałych na terenie dawnych obozów koncentracyjnych i obozów śmierci" ${ }^{14}$. Zdaniem Aleksandry Ubertowskiej podjęcie „problematyki natury, krajobrazu, świata roślin i zwierząt w relacji do Zagłady Żydów"15, niedostatecznie obecnej w refleksji na temat Holokaustu, wynika z tematyki samych narracji, definiujących naturę jako krajobraz symboliczny. Uwzględnienie w tych badaniach klimatu w każdym jego wymiarze, od uwag zawartych w dokumentach, po opisy literackie, tworzone w obrębie fikcji, może przynieść nie tylko wiele ważnych informacji historycznych, ale też przyczynić się do lepszego zrozumienia sposobów mówienia o Zagładzie, zawartych, jak u Kuśniewicza, nie tylko w relacji świadka (bądź kogoś znajdującego się w jego roli), lecz także w metaforach czy metonimiach.

Aby zbliżyć się do kontrowersji wynikających z połączenia refleksji na temat Zagłady z problematyką klimatu, warto rozpatrzyć jeszcze jeden przykład - przywołanej już pracy Welzera. Rezygnując z upodmiotowienia natury, bliskiego Richardowi C. Foltzowi ${ }^{16}$, Welzer założył, że istnieje ścisły związek między katastrofami naturalnymi i społecznymi" ${ }^{17}$. Modelem takiej

13 Tamże, s. 179-180.

14 J. Małczyński Polityka natury w Auschwitz-Birkenau, "Teksty Drugie” 2014 nr 5, s. 141.

A. Ubertowska „Kamienie niepokoją się i stają się agresywne”. Holokaust w świetle ekokrytyki, „Poznańskie Studia Polonistyczne. Seria Literacka”, 2015 nr 25 (45), s. 93.

R.C. Foltz Czy przyroda jest sprawcza w znaczeniu historycznym? Historia świata, historia środowiska oraz to, w jaki sposób historycy moga pomóc ocalić Ziemię, przeł. A. Czarnacka, w: Teoria wiedzy o przeszłości na tle współczesnej humanistyki, red. E. Domańska, Wydawnictwo Poznańskie, Poznań 2010, s. 631-659.

17 Jest to także teza prac Christiana Parentiego, Colina P. Kelley'a, Shahrzada Mohtadi, Richarda Seagera, Yochanana Kushnira, z których wynika, że zmiany klimatu wywołują największe współczesne konflikty polityczne. Nakręcony na podstawie badań m.in. Timothy Snydera, Ri- 
zależności uczynił zniszczenie w 2005 roku przez huragan „Katrina” Nowego Orleanu, które odsłoniło kulisy społeczeństwa i jego dysfunkcje. Innym, ważnym dla Welzera przypadkiem okazała się, ludobójcza w skutkach, wojna plemion z Wyspy Wielkanocnej, które z powodu wycinki lasów palmowych, rozpoczętej około X wieku, dopuściły się ludobójstwa. „Ekologiczna klęska doprowadziła nie tylko do erozji gleby, ale też do erozji kultury"18. Rozważając przede wszystkim konflikty z przełomu XX i XXI wieku, m.in. w Ruandzie i Darfurze, Welzer, autor wielu prac poświęconych Holokaustowi, niejako wpisał tę katastrofę w kontekst wojen klimatycznych i katastrof naturalnych, nie podając jednak powodów tej decyzji ani cech Zagłady zbliżających ją do omawianych zjawisk ${ }^{\mathbf{1 9}}$. Warto spojrzeć na te wątpliwości w perspektywie rozważań Welzera na temat antecedencji Holokaustu, a szczególnie jego początku, które skłoniły badacza do stwierdzenia, że „przyczynowość nie jest kategorią stosunków społecznych, w obrębie społecznych powiązań mogą występować wyraźne napięcia i zagęszczone procesy przemian, ale nic takiego jak decydująca przesłanka, do której wszystko późniejsze dałoby się sprowadzić"20. Czy nie jest to jedna z cech, wyraźnie oddzielających Zagładę od poprzedzonych zapowiedziami katastrofy wojen klimatycznych, która jednocześnie pozwala zobaczyć w nowej perspektywie polskie powieści z lat 1986 i 1987? Praca Haralda Welzera prowokuje do postawienia kilku pytań, które można zadać także wspomnianej prozie: dlaczego psycholog w ogóle poświęcił uwagę Zagładzie w kontekście klimatu? Czy Zagłada mogła mieć w związku z tym charakter wojny klimatycznej? Czy jej antecedensy zdołały przyjąć postać gwałtownych zjawisk klimatycznych? Czy interpretowanie ich poza poetyką (post)katastroficzną w ogóle jest uprawomocnione? Odpowiedź, jaka nasuwa się po lekturze książki, w której ważną rolę odgrywają Pierścienie Saturna W.G. Sebalda, każe spojrzeć na Zagładę jako na jedną

charda Seagera i Christiana Parentiego film dokumentalny The Age of Consequences w reżyserii Jareda P. Scotta z 2016 roku odnosi ich spostrzeżenia do konfliktu w Syrii i pokazuje go przede wszystkim jako konsekwencję wielkiej suszy w latach 2006-2010. Por. Ch. Parenti Tropic of Chaos. Climate Change and the New Geography of Violence, Nation Books, New York 2012; C.P. Kelley, S. Mohtadi, R. Seager, Y. Kushnir Climate change in the Fertile Crescent and implications of the recent Syrian drought, http://www.pnas.org/content/112/11/3241.full (26.03.2017). H. Welzer Wojna klimatyczna..., s. 77.

Katastrofą ekonomiczno-geograficzną nazwał Holokaust także Kenneth Hewitt, wskazując na jej anihilujący i wyniszczający cywilizację charakter. Por. K. Hewitt Regions of Risk. A geographical introduction to disaster, Longman, Essex 1997, s. 326. 
$\mathrm{z}$ katastrof naturalnych ${ }^{21}$, poprzedzoną wymieraniem natury i zakończoną jej kresem ${ }^{22}$. Welzer tak dalece autonomizuje i absolutyzuje w swojej pracy Zagładę, że przypomina ona metonimię w rozumieniu Eelco Runi, czyli „obecność w nieobecności nie w takim sensie, że ukazuje [ona - M.T.] coś, czego tam nie ma, ale w takim, że choć nieobecna (a przynajmniej rażąco niewidoczna) rzecz, której tam nie widać, jednak tam jest obecna"23.

W niniejszym artykule będę szukać odpowiedzi na następujące pytania: czemu służą obrazy katastrof naturalnych w wybranych powieściach dotyczących Zagłady z lat 8o. i czy ich pojawienie się w podobnym czasie wyznacza osobny trend w myśleniu o literaturze, Holokauście i klimacie oraz ich powiązaniach. Ponieważ zrozumienie wspomnianych obrazów wymaga odrzucenia poglądu, że są lub mogą być one częścią dyskursu niewyrażalności bądź przykładem niemocy literatury wobec nazywania społecznych potrzeb i oczekiwań (także względem środowiska naturalnego), na oznaczenie treści, które w tej prozie pulsują, nie zawsze w wyraźny bądź widoczny sposób, przyjmuję pojęcie metonimii jako figury, która z jednej strony umożliwia fluktuację różnych czasów w tekście (np. w Bohini będą to czasy po klęsce powstania styczniowego, II wojna światowa i Zagłada, a w Nawróceniu Zagłada i lata powojenne), a z drugiej daje możliwość szukania w nim treści poza przedstawioną historią czy metafora, niekiedy wbrew intencjom autora. Twórca koncepcji, Runia, nazywa ten sposób myślenia podróżą na gapę historycznej rzeczywistości po historiografii, podkreślając, że chodzi w niej m.in. o pokazanie historycznej nieciągłości bądź splotu ciągłości z nieciągłościąą Jego konsekwencją jest to, że „przetrzymywana” (bądź powstrzymywana) w metonimicznych obrazach historia, podobnie jak suche, upalne lato w Bohini, Weiserze Dawidku czy Zagładzie, wytwarza pewien Stimmung, czyli nastrój,

21 Rozwija ten koncept Paweł Tomczok w szkicu Naturalna historia katastrof. O naturze w prozie W.G. Sebalda , "ArtPapier" 2009 nr 3 (123), http://artpapier.com/index.php?page=artykul\&wydanie $=76 \&$ artykul=1788 (8.07.2016).

Por. A. Ubertowska Natura u kresu (ekocyd) „„Teksty Drugie” 2013 nr 1/2, s. 42. Zasadnicza różnica między poświęconą Sebaldowi lekturą Ubertowskiej i interpretacją Welzera tkwi w postrzeganiu przez oboje badaczy sprawczości natury. Dla Welzera stanowi ona jedynie przedpole dla ludzkiej wojny, dlatego Welzer przechodzi od opisu poligonu wojskowego na wybrzeżu Suffolk z Pierścieni Saturna do pozostałości obozu nazistowskiego Mittelbau-Dora, nie zatrzymując się na opisach dziko rosnących roślin. Natomiast Ubertowska kładzie nacisk na „odsemantyzowanie" Sebaldowskiego pejzażu i odciążenie tekstu przez odebranie naturze wymiaru metafory. 
klimat i atmosferę ${ }^{25}$, które wywołują skojarzenia z katastrofą (burzą, wichurami, powodzią czy zarazą), ale przede wszystkim tworzą znak latentnego stanu rzeczy, który Hans Ulrich Gumbrecht wiąże z powojennym spokojem przesyconym brutalną nerwowością ${ }^{26}$. Idei „uśpienia” doświadczeń wojennych szuka historyk w powojennych zdjęciach z magazynu „Life” z 24 grudnia 1945 roku, na których widać uśmiechnięte młode żony amerykańskich żołnierzy z małymi dziećmi. „Czyżby w dekadzie następującej po 1945 roku coś raczej zniknęło niż się pojawiło?" - pyta Gumbrecht ${ }^{27}$. W obu przypadkach - przemyśleń autora na temat miejsca wojny w dziejach powojennego świata i klimatycznej refleksji o Zagładzie w Bohini, Nawróceniu, Zagładzie czy Weiserze Dawidku - chodzi o obecność, którą Gumbrecht definiuje za Runią jako metonimię ${ }^{28}$. Latencja przypomina atmosferę czy ogólny nastrój, coś ledwie przeczuwanego i nieuchwytnego, ale wzbraniającego się przed prostą interpretacją, polegającą na „wyciągnięciu” znaczenia „na wierzch”. Pełnia spokoju intensyfikuje doświadczenie przemocy, zdaje się mówić Gumbrecht na podstawie tużpowojennych zdjęć wybuchu wulkanu czy maszynki do golenia dotykającej policzka niemowlęcia. Podobnie można myśleć o obrazach wichury czy powodzi towarzyszących wypowiedziom o Zagładzie bądź je zastępującym, które nadchodzą po skwarnym lecie. Opisy zmian pogodowych są w tych powieściach nie tylko częścią dyskursu na temat historii, ale także składową wypowiedzi o teraźniejszości i przyszłości. Nie tylko zasłaniają (opowieść o Zagładzie czy relacjach polsko-żydowskich przed wojną i w jej czasie), ale i odsłaniają (nastroje panujące w Polsce wobec zmian klimatu w latach 70. i 8o., a także początki literackiej historii środowiskowej). Tworzą wreszcie nie metafory, za którymi nic się nie kryje, ale głos troski pisarzy o klimat, łączący narrację o Zagładzie z postawą czujności wobec zmian zachodzących w środowisku naturalnym.

Ponieważ żadna z tych metonimicznych powieści nie jest powieścią holokaustową bądź postholokaustową w rozumieniu Efraima Sichera ${ }^{29}$, proponuję

Por. H.U. Gumbrecht Po roku 1945. Latencja jako źródło współczesności, przeł. A. Paszkowska, Wydawnictwo Krytyki Politycznej, Warszawa 2015, s. 45-46.

Tamże, s. 45 .

Tamże, s. 44.

Tamże.

Sicher za podstawę obu określeń przyjął dość oczywiste wyznaczniki, takie jak rozległość i dokładność omawianego tematu oraz biograficzny związek pisarza z Zagładą. Ale nie we wszystkich przypadkach pozostał tej zasadzie wierny, nazywając np. Zagładę, Umschlagplatz 
w odniesieniu do nich używać sformułowań typu „powieść o Zagładzie” bądź „narracja o Zagładzie” w bardzo ogólnym znaczeniu. Szczególnie, że w utworach takich jak Bohiń czy Zagłada Szewca można znaleźć wiele innych skojarzeń bądź literalnych wypowiedzi historycznych. Z kolei w powieści Huellego Zagłada stanowi istotny dla biografii jej bohaterów background. Wiąże się on z gettem w Brodach, w którym prawdopodobnie zginęli rodzice Dawida Weisera $^{30}$. Ale już czas głównej akcji przypada na rok 1957. Jedynie w przypadku rozległych retrospektyw z Nawrócenia możemy mówić o narracji holokaustowej, która pojawia się zarówno w dosłownej, jak i metaforycznej warstwie tekstu.

\section{Dwa przypadki: Bohiń i Nawrócenie}

Zestawienie Bohini z Nawróceniem, Weiserem Dawidkiem i Zagłada nie jest pomysłem nowym. Pisali o nim zarówno recenzenci powieści z 1987 roku, dla których proza Konwickiego stanowiła układ odniesienia, jak i autorzy większych opracowań, tacy jak Jerzy Jarzębski czy Przemysław Czapliński. Jednak żaden z nich nie uczynił z refleksji klimatycznej problemu na nowo oświetlającego tematykę Zagłady ${ }^{31}$. Ekocyd opisywany w tych powieściach najczęściej sprowadzano do spostrzeżeń z zakresu metaforyki apokaliptycznej i katastroficznej, jak uczynił to w komentarzu do powieści Piotra Szewca Arkadiusz Morawiec:

Zagłada w pierwszym znaczeniu [Holokaustu - M.T.] nie została ukazana w powieści w sposób bezpośredni - stąd nieporozumienia. Zapowiadają ją wszakże liczne znaki, sugestie [...]. Na pozór zagłada zdaje się nie dotyczyć ludzi; słowo to pojawia się w odniesieniu do zjawisk przyrody, deszczu, powodzi, suszy i pożaru, funkcjonuje „zaledwie” jako człon porównania [...]. Jednym ze znaków, iście wieszczych, znamionujących nieszczęście, jest wielokrotnie wspominany w utworze spadający za

Jarosława Marka Rymkiewicza czy Poczq̨ek Andrzeja Szczypiorskiego powieściami postholokaustowymi. Por. E. Sicher The Holocaust Novel, Routledge, New York-London 2005, s. 1-51; 89-110.

Piszę o tym w pracy Metonimie Zagłady. O polskiej prozie lat 1987-2012, Wydawnictwo UŚ, Katowice 2013, s. 281-287. 
miastem meteoryt, widniejący też, pod postacią ognistej kuli z warkoczem dymu i iskier, na wspomnianym obrazie. ${ }^{32}$

Podobnie pisał o Bohini Krzysztof Rutkowski:

W najnowszej powieści Tadeusza Konwickiego pod tytułem „Bohiń” z ziemi i niebios dobywa się grzmot i promieniuje dziwna jaskrawość, do niczego niepodobna, a straszna. I panoszy się upał końca lata zawieszonego pośród wyblakłych kolorów w bezczasie. Ów straszny dźwięk słyszy babka autora, pani Helena Konwicka i on sam, bo poprzez czas znalazł się sam na skrawku wileńskiej ziemi w wigilię wielkiej apokalipsy, by tropić własny los i dzieje nas wszystkich. ${ }^{33}$

Tym, co zbliża do siebie omawiane powieści, jest obraz upalnego i bezdeszczowego lata. „Mijały pierwsze dni lipca. W upale i duchocie miasto pozbawione zatoki zdawało się ledwie dychać, a zupa rybna gęstniała i gęstniała, przysparzając władzom miejskim coraz to nowych kłopotów [...]. Przypomniano również, że od dwóch miesięcy to jest od początku maja, nie spadła ani jedna kropla deszczu..." (WD, 32) - pisze Huelle. Bohaterowie Bohini narzekają na "straszny upal” (B, 20) i „żar” (B, 20), które mają przynieść zmianę pogody, odczuwaną przez jaskółki, gżegżółki i gawrony. W Zagładzie panuje wręcz lipcowa susza. Wysychają źródełka i ciała martwych zwierząt (Z, 34). Jedynie w Nawróceniu upał przerywa bezdeszczowa, sucha burza o sile trąby powietrznej. „A ktoś nam mówił, że wszystko fruwało, co tylko latać mogło. Taka trąba powietrzna. Prawdziwy cyklon" (N, 144-145). Oprócz komentarzy, że letnia susza oznacza „gniewną dłoń bożą” (N, 144) czy „karę boską” (WD, 32), autorzy nie wyjaśniają przyczyn, dla których tak obficie sięgają po obrazy zmieniającej się pogody. A jest to obfitość zaiste zastanawiająca. W Bohini mówi się o powodzi, nawałnicy, burzy, dźwięku spod ziemi, kometach i meteorytach, chociaż najczęściej, bo pięciokrotnie, powraca motyw burzy. Nawet powstanie styczniowe przypomina narratorowi letnią burzę $(B, 19)$, która nagle wybuchła i ucichła, co ze względu na zimową porę roku tamtego wydarzenia wydaje się skojarzeniem zastanawiającym. W Weiserze Dawidku przeważa obraz wypalonej wściekłym słońcem ziemi i zatrutego morza oraz

A. Morawiec Literatura w lagrze. Lager w literaturze. Fakt - temat - metafora, Wydawnictwo Akademii Humanistyczno-Ekonomicznej w Łodzi, Łódź 2009, s. 339-340.

K. Rutkowski Tadeusz Konwicki: szósta pieczęć, „Kultura Paryska” 1988 nr 7-9, s. 207. 
„setek śniętych węgorzy, fląder, śledzi i innych ryb [...]. Wszystko to, na pół przegniłe i strasznie cuchnące, ruszało się w drgawkach. Szczególnie węgorze, najsilniejsze ze wszystkich ryb, umierały długo. Ich wijące się ciała pamiętam do dzisiaj, niczym symbol tamtego lata" (WD, 111). Katastrofę w postaci powodzi opisuje najchętniej Szewc. Jest to jednak albo powódź śniona: „powódź zalała miasto, w wodzie pływają ludzkie głowy - jego, Herszego Bauma, a także żony Zeldy i ich pięciorga młodziutkiego potomstwa - chyba połowy mieszkańców miasta" (Z, 8), albo... powódź z wody i piwa na stoliku w szynkwasie, która:

Jakby zagłada jakaś (pamiętajmy: deszcze ulewne, jakie przez tydzień szalały na okolicą, pomiędzy większymi kępami traw - krupówki, tymotki, rajgrasy - między kępami białych koniczyn, krwawnika, we wgłębieniach po kopytach konia zostawiły kałuże wody, mikroskopijne bagienka, których woda przedestylowana przez listki i czas), która bywa powodzią zatapiającą miasto, również powodzią, która niszczy porządek łąki wiosną, ale też suszą, kiedy bagienka schną na łąkach, pożarem, który pali wszystko - należy się cofnąć kilka kroków i odwrócić twarz - zatem: jakby zagłada jakaś chciała zabrać pamięci pejzaż tych nitek i kropli. $(\mathrm{Z}, 36)$

We wszystkich czterech powieściach powracają także obrazy komety i spadających meteorytów. „Ale panna Helena nie wiedziała, że to spadają meteoryty, i nie wiedziała, że gdzieś tam w mroźnej przestrzeni nad nami leciała wtedy pewna kometa, która zginęła kiedyś później w nieskończonych koleinach" (B, 31); „W oddali, gdzie meteoryt w zboże spadł, rozpędzony, dudniący głucho zatrzymuje się pociąg. Warkocz iskier wzbija się w ciemność z sykiem...” (Z, 125); „Byli też tacy, którzy widzieli kometę w kształcie końskiej głowy, jak krążyła nad miastem, i ci, którzy ją widzieli, zaklinali się, że kometa powróci po okrążeniu Ziemi i spadnie ze straszliwą siłą" (WD, 112); "Ogon komety omiata domy na wybrzeżu, pensjonaty, hotele, pusty Strand, by za moment - odwracając bokiem, ślizgać się po łagodnych garbach fal unoszących się i zapadających w powolnym rytmie" $(\mathrm{N}, 123)$.

Aby wyjaśnić związek tych zjawisk z Zagładą, ograniczę się do omówienia dwu powieści: Bohini i Nawrócenia. Ich wybór wynika m.in. z wyjątkowej intensywności opisów natury i gwałtownych zjawisk atmosferycznych. Pozwala także zobaczyć metonimie Zagłady w dwojakim układzie: jej zapowiedzi i samego Holokaustu. 
W powieści Konwickiego latentna wydaje się przede wszystkim relacja Żyda Eliasza Szyry z Polką Heleną Konwicką. Odczytywano ją nie tylko jako romans, lecz także jako zaproszenie do poważnej dyskusji na temat relacji polsko-żydowskich w XIX i XX wieku³4. Symbolem Zagłady uczynił Konwicki postać ludojada Schickelgrubera, ludowe wcielenie Adolfa Hitlera, straszącego w lasach Wileńszczyzny i palącego żydowskie wioski. Największa burza w Bohini, na którą wszyscy czekają jak na koniec świata, jest jego dziełem. Konwicki nazywa ją „nocą Schickelgrubera”, który „lubi palić ludzi. Najlepiej Żydów" (B, 107) i upodabnia do trzęsienia ziemi, podczas którego Helena krzyczy: „Niech on [Schickelgruber - M.T.] wreszcie spali nas wszystkich, nasze domy, nasze lasy, nasze cmentarze!" (B, 173). Początek burzy przypomina pierwsze chwile wojny ${ }^{35}$ :

Ptaki uciekały nisko nad ziemią do nieznanych kryjówek [...] i ludzie biegli z pól ku zabudowaniom folwarcznym. [...] Potem błyskało coraz częściej. [...] Te wężyki niebieskawego światła przerzynały granat nieba w milczeniu i można było pomyśleć, że to małanka, tak częsta podczas letnich dusznych nocy błyskawica bez grzmotu, jakiś zabłąkany refleks dalekiej burzy, co innym ludziom zabija zwierzęta na polach i zapala domy. [...] Potem jednak po którejś z tych niemych błyskawic zadudniło jakby spod ziemi i wreszcie w którymś momencie uderzył piorun gdzieś w stronie Miłowidów. [...] Stare drzewa o czarnych pniach ożyły teraz, szumiały, huczały przejmująco, czasem gdzieś pękła gałąź albo martwy pień. [...] I wtedy usłyszała rzadki łopot pierwszych kropli deszczu i liście parku, kropli wielkich jak wiśnie, wymieszanych z ogromnym gradem. [...] Ojciec patrzył przez okno, na pociemniały i poszarzały świat, na mały świat Bohini, do której zbliżał się naprawdę koniec świata. [...] Ale już tam pośrodku lasu podnosiła się z wolna różowa łuna. Gdzieś palił się jakiś zaścianek albo umierający smolisty las. $(\mathrm{B}, 102)$

Szyra nie ginie jednak od pioruna, lecz z rąk ojca Heleny, Polaka. Nie jest to mord sąsiedzki, ale szlachecki. U jego podstaw leży hańba, której dopuściła

34 Chociaż nie wszyscy to zaproszenie przyjęli. Jeden z najbardziej negatywnych głosów krytyki nakazywał wręcz "udaremnić odczytanie Bohini w ramach mody na tematykę żydowską". Por. A.N. [Anna Nasalska] Bogini, w: „Kultura Niezależna” 1988 nr 43, s. 110. 
się Helena, zachodząc w ciążę z Żydem. Zagłada przedstawiona pod postacią burzy rozpętanej przez niemieckiego ludojada staje się więc tłem do ukazania pojedynczych losów żydowsko-polskich, stworzonych przez sytuacje znane z ostatniej wojny, takie jak ukrywanie i zabijanie Żydów przez Polaków, polska pogarda i wyniosłość wobec żydowskich sąsiadów czy udział Żydów w polskiej polityce. Nie są to jednak treści, które Konwicki uczynił „przedstawianą historią" ${ }^{\text {"36 }}$, lecz "przewidywaną retrospekcją" ${ }^{37}$, czyli projektem, w jakim przeszłość odnosi się do przyszłości, a teraźniejszość tworzy shifting baselines. Jednym z punktów odniesienia jest zagłada całej okolicy: „choć ona zginie, szczeźnie przywalona historią i czasem, to żyć będzie roznoszona po całej ziemi przez cząstki naszego ciała" (B, 101). Zagładę wszystkiego dostrzega współczesny narrator, który przedziera się „na tamten brzeg” (B, 6) przez ogromną powódź. Zwiastunem końca roślin, ludzi i zwierząt uczynił Konwicki głęboki i przeraźliwy dźwięk spod powierzchni ziemi (B, 23), który najczęściej słyszy Helena, identyfikując go z jej zmęczeniem $(B, 165)$. Wydaje się, że to w tym dźwięku skrystalizował pisarz swoje rozmaite obawy, i ekologiczne, i polityczne, we wnioskach zbliżając się do Freda Pearce'a, twierdzącego, że ziemia jest „dziką bestią, zdolną do gwałtownej reakcji, do której już niedługo będzie gotowa"38: „zemsta natury za wywołane przez człowieka globalne ocieplenie najprawdopodobniej wyzwoli nieposkromione siły planety. I będą one nagłe i gwałtowne"39.

Nawrócenie stanowi w pewnym sensie odpowiedź na przestrogę Pearce'a. Zagłada w tej powieści przedstawiona jest jako gwałtowane załamanie klimatu, wywołane szkodliwą działalnością człowieka. Przypomina nie tyle ekocyd, ile „zemstę natury”, ale zemstę niezrozumiałą i niesprawiedliwą, ponieważ spadającą tylko na naród żydowski. Dawni żydowscy znajomi bohatera-narratora, mieszkańcy Kowenic i Sambora, nakłaniają go, aby opisał swoje przedwojenne wspomnienia dotyczące Żydów:

36 E. Runia Obecność..., s. 76.

Jest to określenie zapożyczone przez Haralda Welzera od Alfreda Schütza. Por. A. Schütz Terezjasz, czyli nasza wiedza na temat przyszłych zdarzeń, w: O wielości światów. Szkice z socjologii fenomenologicznej, przeł. B. Jabłońska, Nomos, Kraków 2008, s. 189-201.

A. Giddens Klimatyczna katastrofa, przeł. M. Głowacka-Grajper, Prószyński i S-ka, Warszawa 2010, s. 36.

F. Pearce The Last Generation, Eden, London 2007, s. 26. Cyt. za: A. Giddens Klimatyczna katastrofa..., s. 36 . 
Patrzę dokoła - a tu nikogo. Jakby wymiótł. Kurz tylko porwany nagłym podmuchem zakołował, uniósł się aż na wysokość ratuszowej wieży. Istna trąba powietrzna. A dołem zatańczyły różne niedopałki, ogryzki jabłek, stare bilety kolejowe, ba, bilety loteryjne [...]. Wiatr dmucha od strony miasta ku polom i rzece. Od wąskich zaułków dzielnicy zakazanej, zamkniętej, zwanej „Zarzeczem”. I od okolicy małego podejrzanego hoteliku na rogu ulicy Berka Joselewicza. (N, 101)

Jeszcze dobitniej przedstawia Kuśniewicz likwidację żydowskiej ludności Sambora. Ginie ona od zarazy wywołanej przez „niski obłok Shoach”40 $(\mathrm{N}, 118)$ :

No bo - wielka zaraza. Mają zatkane jamy ustne i nosy watą i szmatami. Szmaty te są nasycone jakimś żółtym olejem. Żeby na tyle, na ile się da, ochronić przed oddechem zatrutego jadu. Ten zły oddech, to zatrute powietrze, powiadają świadomi - pełza zazwyczaj nisko. Najczęściej tuż nad walającymi się wszędzie nie sprzątniętymi jeszcze zwłokami [...]. Złe wonie, zatrute elementy atmosfery sączą się również poprzez szpary w deskach, którymi zabito otwory okien w pustych mieszkaniach na piętrach. $(\mathrm{N}, 118)$

Kuśniewicz, oddając do druku powieść na długo przed 1987 rokiem, nie mógł znać konsekwencji o rok wcześniejszej katastrofy w elektrowni jądrowej w Czarnobylu, a szczególnie skutków przesuwania się chmury radioaktywnej, która wędrując w kierunku Skandynawii, zatrzymała się nad Opolszczyzną, powodując w okolicach Olesna i Łambinowic stężenie radiocezu stukrotnie większe niż średnie wówczas skażenie w Polsce ${ }^{41}$. Sądzę, że znajomość następstw tamtego zdarzenia pozwala jednak zobaczyć w „obłoku Shoach” więcej niż pisarską fantazję. Metonimia Zagłady odsłania przed czytelnikiem dwie katastrofy równocześnie: tę, która rzeczywiście dotknęła samborskich Żydów, i tę, która mogła była dotknąć tamtą ludność, choć dotknęła innych ludzi w zupełnie innym czasie.

Można by zapytać, dlaczego Kuśniewicz przedstawia Zagładę jako niszczącą wszystko wichurę, trąbę powietrzną, orkan czy huragan i czy w jego

40 Taka pisownia w tekście.

41 A. Grudzka Co nam zostało po Czarnobylu, http://www.nto.pl/magazyn/reportaz/art/4166081,co-nam-zostalo-po-czarnobylu,id,t.html (10.07.2016). 
narracji zmiana klimatu sprowadza się tylko do metafory. Częstotliwość występowania porywistych wiatrów i huraganów w Nawróceniu pozwala przyjąć założenie, że Kuśniewicz rozumie Zagładę znacznie szerzej niż koniec świata ludzi. Siejący spustoszenie orkan niszczy przecież także ekosystem, w tym rośliny i zwierzęta, pozostawiając po sobie pustkę i nieurodzaj. Jak w scenie „towarzyszącej” śmierci Żydów, a poświęconej masakrze ptaków: „Powiadano, że nawet ptaki ciskało na boki i z góry na dół, wyłamując im skrzydła i otwierając dzioby ochrypłe od krzyku" (N,153). Jednocześnie trudno zgodzić się ze stwierdzeniem, jakoby metonimie Zagłady uniemożliwiały Kuśniewiczowi czy Konwickiemu wypowiadanie się na temat polsko-żydowskich relacji przed wojną, w jej czasie i po niej.To, co autor Bohini pokazuje na przykładzie kilkuosobowego dramatu, Kuśniewicz przedstawia w formie śmiałych tez i uogólnień, stając się oprócz Romana Zimanda, autora wydanego w 1987 roku Piołunu i popiołu, najostrzejszym krytykiem zarówno polskiego antysemityzmu, jak i żydowskiej polonofobii. To z Nawrócenia pochodzą słowa „Przecież gdyby nie czynny współudział władz, ale nie tylko, bo i społeczeństwo nie było bez grzechu - ani Drancy nie byłoby możliwe, ani masowe wywózki do Auschwitz, wydawanie Niemcom ludzi, łapanki organizowane przy udziale różnych Légion i faszyzujących organizacji młodzieżowych" (N, 190). A także uwaga, spajająca Bohiń, powieść o żydowskim powstańcu, z prozą Kuśniewicza: „A tylu patriotów żydowskiego pochodzenia w powstaniu styczniowym?” $(\mathrm{N}, 191)$.

\section{Zmiany klimatu: zakończenie}

Fluktuacja czasów składająca się na metonimie otwiera jeszcze jedną możliwość ich rozumienia, bliską przede wszystkim samym piszącym. Możliwość zapisania w obrazach Zagłady trosk o klimat i jego przemiany w Polsce lat 8o. Zapytany o nią wprost Piotr Szewc nie wykluczył tej ewentualności, choć uznał ją za mało prawdopodobną. Stwierdził natomiast, że w jego pamięci, towarzyszącej czasom powstania Zagłady (lata 1981-1983), zapisała się przede wszystkim zima stulecia z końca siódmej dekady ubiegłego wieku ${ }^{42}$. Tymczasem zarówno z publikacji polskiego Instytutu Meteorologii i Gospodarki Wodnej, jak i z prac Antony'ego Giddensa i Naomi Klein wynika, że chociaż zmiana klimatyczna, najczęściej wiązana z ociepleniem, dała o sobie znać dopiero w latach 2000, niektóre jej skutki zaczęto odczuwać już w latach 80. 
Do 1988 roku zanieczyszczenie powietrza w Polsce było bardzo wysokie ${ }^{43}$. Jak podają Krzysztof Klejnowski, Wioletta Rogula-Kozłowska i inni „w latach 80. straty materialne, jakie Polska ponosiła w wyniku zanieczyszczenia powietrza, wyniosły około 5\% dochodu narodowego" 44 . Warto porównać tę sytuację z osiągnięciami liderów w dziedzinie ochrony środowiska. Od początku lat 8o. Szwecja zaczęła korzystać z energii atomowej i wodnej, jednocześnie zmniejszając import paliw kopalnianych, a w 1980 roku przeprowadziła wśród obywateli referendum, którego wyniki zmusiły państwo do stopniowego wycofywania się z energii atomowej ${ }^{45}$. W Niemczech zamknięcie wielu elektrowni atomowych oraz znaczące zwiększenie udziału elektryczności ze źródeł odnawialnych, czyniące ten kraj światowym liderem produkcji w dziedzinie energetyki wiatrowej i słonecznej, było efektem postanowień z początku lat 8o. XX wieku ${ }^{46}$. W 1988 roku powołano Międzynarodowy Zespół do spraw Zmian Klimatu przy ONZ (IPCC). Wedle sugestii jego pracowników wzrost temperatury na świecie o ponad $3^{\circ} \mathrm{C}$ spowoduje, że „pokrywa Grenlandii zacznie się topić, a kiedy ten proces nastąpi, nie będzie szans go odwrócić"47. Tych kilka informacji wystarczy, aby zauważyć, że ósma dekada XX wieku nie tylko dla świata, ale także dla Europy Zachodniej okazała się czasem pierwszych poważnych reakcji przeciwko ociepleniu klimatu.

Z analiz IMGW wynika, że lata 8o. należały w Polsce do ciepłych, a przede wszystkim suchych. Wyjątek stanowił rok 1980, który oprócz 1956 roku był najchłodniejszym polskim rokiem w wieloleciu 1951-2008 ${ }^{48}$. Z kolei „najniższa średnia obszarowa suma opadów wystąpiła w 1982 roku i była skutkiem

43 K. Klejnowski, W. Rogula-Kozłowska, B. Błaszczak, L. Ośródka, E. Krajny Problemy zanieczyszczeń powietrza, w: Zmiany klimatu a monitoring i prognozowanie stanu środowiska atmosferycznego, red. M. Ziemiański, L. Ośródka, Instytut Meteorologii i Gospodarki Wodnej - Państwowy Instytut Badawczy, Warszawa 2012, s. 111

44 Tamże.

45 A. Giddens Klimatyczna katastrofa, przeł. M. Głowacka-Grajper, Prószyński i S-ka, Warszawa 2010, s. 85 .

Tamże, s. 86. Tamże, s. 34 .

48 D. Limanówka, D. Biernacik, B. Czernecki, R. Farat, J. Filipiak, T. Kasprowicz, R. Pyrc, G. Urban, R. Wójcik Zmiany i zmienność klimatu od połowy XX wieku, w: Warunki klimatyczne i oceanograficzne w Polsce i na Bałtyku Południowym. Spodziewane zmiany i wytyczne do opracowania strategii adaptacyjnych w gospodarce krajowej, red. J. Wibig, E. Jakusik, Instytut Meteorologii i Gospodarki Wodnej - Państwowy Instytut Badawczy, Warszawa 2012, s. 8. 
trwającej 11 miesięcy (od lutego do grudnia) suszy"49. Zjawisko suszy, mające w Polsce charakter anomalii pogodowej, trwało z przerwami od 1982 do 1984 roku, powodując zniszczenia i utrudnienia przede wszystkim w rolnictwie ${ }^{50}$. Silne minimum średniego obszarowego rocznego stopnia zachmurzenia ogólnego odnotowano w 1982 roku. Z kolei lata 1980-1989 okazały się, szczególnie na tle siódmego dziesięciolecia ubiegłego wieku, bardzo wietrzne, z przewagą wiatrów porywistych (przede wszystkim w 1985 i 1989 roku) ${ }^{51}$. Warto uzupełnić, że dopiero po 2005 roku do Polski dotarły najbardziej niszczycielskie cyklony huraganowe, takie jak BRITTA, CYRYL czy EMMA ${ }^{52}$. Nie zmienia to faktu, że omawiane dziesięciolecie na tle poprzednich dekad wyróżnia się istotnymi zmianami pogodowymi.

Czy tego typu informacje mogły mieć jakikolwiek wpływ na fabułę omawianych powieści, a szczególnie na ich warstwę latentną? Przypomnijmy, że tworzenie skomplikowanego systemu ukrytych znaczeń, a właściwie splotu znaczeń nietworzącego żadnego systemu, opiera się na założeniu, że jego istnienia nigdy nie możemy być pewni, taka pewność przeczyłaby bowiem strukturze latentnego, o której pisał Gumbrecht, że nie tkwi w głębi właśnie dlatego, aby jej nie wydobywać na drodze interpretacji ${ }^{53}$. Ponadto prawdopodobieństwo, że metonimie Zagłady przenikają treści dotyczące klimatu, jest przynajmniej takie samo, jeśli nie większe, jak w przypadku odniesień apokaliptyczno-katastroficznych. Z jedną wszakże różnicą. Claus Leggewie i Harald Welzer zwracali uwagę, że odczytywanie zmian klimatycznych jako zjawisk nadnaturalnych było charakterystyczne dla czasów przednowożytnych ${ }^{54}$. Pojawienie się pojęcia „katastrofa” pociągnęło za sobą przede wszystkim skutki społeczno-kulturowe, powodując, że jej rozumienie zaczęto sprowadzać do nagłych zdarzeń, przypominających wybuch czy cezurę. Określenie „zmiana klimatyczna” ma w tym kontekście wymiar naukowy i wskazuje na

49 Tamże, s. 18.

50 L. Łabędzki, J. Leśny Skutki susz w rolnictwie - obecne i przewidywane w zwiq̨zku z globalnymi zmianami klimatycznymi, „Wiadomości melioracyjne i łąkarskie” 2008 nr 1, s. 7-9.

H. Lorenc Struktura maksymalnych prędkości wiatru w Polsce, w: Klęski żywiołowe a bezpieczeństwo wewnętrzne kraju, red. H. Lorenc, Instytut Meteorologii i Gospodarki Wodnej - Państwowy Instytut Badawczy, Warszawa 2012, s.36. Tamże, s. 42. H.U. Gumbrecht Po roku 1945 .., s. 45.

54 C. Leggewe, H. Welzer Koniec świata, jaki znaliśmy. Klimat, przyszłość i szanse demokracji, przeł. P. Buras, Wydawnictwo Krytyki Politycznej, Warszawa 2012, s. 31. 
stopniowy, dający się często przewidzieć proces narastania zjawiska 55 (jak w przypadku skutków działania huraganu Katrina, który w 2005 roku nawiedził Nowy Orlean, częściowo opisanych w 2001 roku przez „Scientific American"56). Sądzę, że więcej korzyści przynosi rozpatrywanie obrazów Zagłady w kontekście zmian klimatycznych, a także zwrócenie uwagi na to, jakiego rodzaju wypowiedź o Holokauście one tworzą, niż porzucenie tej intuicji. Jej rozwinięcie stwarza też szansę zobaczenia prozy lat 8o. jako nowej, odważnie sformułowanej tezy o splocie genocydu z ekocydem i myślą o klimacie, weryfikującej ogólnie znane ustalenia o jej koncyliacyjnym i zamazującym historię charakterze ${ }^{57}$. Jest to zarazem splot, jak pisała Ewa Domańska w związku z humanistyką ekologiczną, zupełnie różny od piramidalnej metafory widzenia rzeczywistości, osadzony wśród takich pojęć, jak splątane relacje, sieci, pokrewieństwa czy wspólnoty ${ }^{58}$. W przypadku omówionych metonimii Zagłady nie sposób więc mówić o prostym wpływie obserwacji naukowych czy wyników badań środowiskowych na literaturę. Chodzi raczej o pokazanie sytuacji, w której wspomniana już wcześniej klęska ekologiczna oddziałuje na erozję kultury, tworząc kulturowe systemy odniesienia, dotyczące także Zagłady ${ }^{59}$.

55 Tamże.

56 H. Welzer Wojny klimatyczne..., s. 43.

57 Zwracał na to uwagę przede wszystkim Przemysław Czapliński, używając w odniesieniu do Poczq̨tku Andrzeja Szczypiorskiego i Weisera Dawidka dwu celnych formuł: „melancholia osamotnionych Polaków” oraz "Żydzi bez Holokaustu”. Wprost o przemilczeniach w literaturze lat 8o., a szczególnie w Zagładzie, pisała Anna Mach, sprowadzając jej zawiłości do wynikającego ze słabości i lęku (autora książki? Czasów? Literatury?) języka ezopowego. Por. P. Czapliński Zagłada-niedokończona narracja..., s. 345-355; A. Mach Świadkowie świadectw..., s. 218. 
Abstract

Marta Tomczok

UNIVERSITY OF SILESIA (KATOWICE)

A Climate of Annihilation (in Novels by Paweł Huelle, Tadeusz Konwicki, Andrzej Kuśniewicz and Piotr Szewc)

This article suggests possibilities of reading novels by Tadeusz Konwicki, Andrzej Kuśniewicz, Piotr Szewc and Paweł Huelle through the prism of environment-oriented studies on the Shoah. Where Polish narratives of the Holocaust are concerned, Tomczok proposes, the years 1986 and 1987 saw not only a breakthrough in terms of politics and worldview, but also a shift in writers' perception of climate change and the rapid degradation of the environment. Building on studies by Eelco Runia and Hans Ulrich Gumbrecht, Tomczok reads natural disasters as metonymies of the Shoah - metonymies that point to the extermination of the Jews while also reflecting on contemporary threats to the natural environment. Tomczok's proposition to relate these two perspectives draws on Harald Welzer's Climate Wars: What People Will Be Killed For in the 21st Century. The article also contextualizes selected novels by the above-mentioned writers with Polish climate research conducted in the 1980s at the Institute of Meteorology and Water Management - National Research Institute.

\section{Keywords}

Holocaust, climate, natural disaster, metonymy, novel 